DOI

\title{
ОРГАНІЗАЦІЯ САМОСТІЙНОЇ РОБОТИ СТУДЕНТІВ ЗАОЧНОЇ ФОРМИ НАВЧАННЯ $З$ ДИСЦИПЛІНИ “БІОЛОГІЧНА ХІМІЯ” В УМОВАХ КРЕДИТНО-МОДУЛЬНОЇ СИСТЕМИ
}

\author{
I. В. Ніженковська, О. В. Кузнецова \\ Національний медичний університет імені О. О. Богомольця

\section{THE ORGANIZATION OF INDEPENDENT WORK OF STUDENTS WITH EXTERNAL FORM OF STUDIES ON THE SUBJECT "BIOLOGICAL CHEMISTRY” IN THE CREDIT-TRANSFER SYSTEM}

\author{
I. V. Nizhenkovska, O. V. Kuznetsova \\ National Medical University by O. O. Bohomolets
}

\begin{abstract}
Висвітлено особливості організації самостійної роботи студентів заочної форми навчання у процесі вивчення біологічної хімії в Національному медичному університеті імені О. О. Богомольця. Визначено дидактичні умови підвищення ефективності професійної підготовки фахівців фармацевтичної галузі. Вирішення означених задач сприятиме активізації самоосвіти студентів заочної форми навчання вищих медичних (фармацевтичних) навчальних закладів.
\end{abstract}

The peculiarities of students' independent work organization on the subject "Biological Chemistry" at O. O. Bohomolets National Medical University have been analysed. Didactic conditions of professional training efficiency increase for the specialists of pharmaceutical industry have been identified. The solution to these problems will help to intensify the teaching process for students of external form of education in Higher Medical (Pharmaceutical) Educational Institutions.

Вступ. В умовах зростання ролі знань і освіти як для кожної особистості, так і для всього суспільства особливе завдання покладається на вищу освіту. Останні роки підтвердили, що заходи із вдосконалення вищої освіти в Україні були вчасними і невідкладними [1, 2]. У рамках Болонського процесу наказом МОН від 16 жовтня 2009 р. № 943 у вищих медичних навчальних закладах України III-IV рівнів акредитації введено Європейську кредитнотрансферну систему (ЄКТС) [3]. Серед переваг організації навчального процесу за стандартами ЄKTC є формування мотиваційного стимулу для систематичного навчання студентів, підвищення ролі самостійної роботи студентів (СРС), яка спрямована на виховання їх творчої активності, стимулювання професійного зростання. Тому організація самостійної роботи на сучасному етапі розвитку вищої школи набуває особливого значення.

Одною із форм здобуття вищої освіти особами, які мають відповідний освітньо-кваліфікаційний рівень, є заочна форма навчання [4]. Навчальний процес за заочною формою навчання здійснюється під час сесії й у міжсесійний період. Особливість навчального плану заочної форми навчання полягає

\footnotetext{
(с) І. В. Ніженковська, О. В. Кузнецова
}

у тому, що загальний обсяг годин на вивчення конкретної дисципліни, форма підсумкового контролю відповідають навчальному плану денної форми навчання, а обсяг СРС становить понад 80 \% від загальної кількості годин.

Основна частина. 3 вересня 2014 року у Національному медичному університеті імені О. О. Богомольця на заочному відділенні фармацевтичного факультету розпочато підготовку фахівців в умовах кредитно-модульної системи організації навчального процесу. Навчальний план для студентів заочної форми навчання терміном 2,5 роки за спеціальністю 7.12020101 “Фармація” розроблений з урахуванням 198 академічних годин з дисципліни "Біологічна хімія”, що були опрацьовані студентами під час здобуття ними освітньо-кваліфікаційного рівня бакалавра, і передбачає для вивчення біологічної хімії 108 годин, із них 17 годин - аудиторні заняття, а 91 година - СРС. Отже, самостійна робота є основним шляхом засвоєння студентами заочної форми навчання та навчального матеріалу у вільний від аудиторних занять час. За мету СРС з дисципліни “Біологічна хімія” ставить оволодіння глибокими і міцними знаннями основних понять і закономірностей біохімії, набуття умінь та навичок якісного 
та кількісного визначення в основних рідинах організму (кров, сеча) проміжних та кінцевих продуктів обміну речовин, самостійного аналізу біохімічних процесів в організмі у нормі та при патології, формування хімічного і біологічного мислення. Зміст самостійної роботи при вивченні біологічної хімії визначається робочою навчальною програмою, підручниками, навчальними посібниками, методичними вказівками і тестовими завданнями бази “Крок 1. Фармація".

Вітчизняний і зарубіжний досвід показує, що організація СРС повинна бути спрямована на більш повну реалізацію завдань навчання, формування професійно важливих якостей особистості фахівця, стійку позитивну мотивацію до самоосвіти та самовдосконалення, комплексний інноваційний розвиток системи освіти. Виходячи з цих параметрів, основні принципи організації самостійної роботи студентів заочної форми навчання $з$ дисципліни “Біологічна хімія” наступні:

- принцип опори на базові знання та вміння, що передбачає теоретичну підготовку студентів з медичної біології, неорганічної, аналітичної, фізикоколоїдної та органічної хімії, фізіології та мікробіології, наявність у студентів мінімальних навичок роботи з лабораторним посудом та приладами й уміння раціонально використовувати вільний час для організації самостійної роботи;

- принцип науковості, який дозволяє студенту вирішувати поставлені завдання на сучасному рівні наукових знань;

- принцип зв'язку теорії з практикою, що дає можливість проводити лабораторні дослідження, вирішувати ситуаційні задачі;

- принцип регламентації навчання, який відображає стратегію навчання і планування організації СРС;

- принцип доступності та посильності самостійної роботи, що забезпечує спрямованість самостійної роботи на активізацію, розвиток розумової діяльності студента, формування здатності самостійно прогнозувати, вибирати і вирішувати дидактичні завдання;

- принцип наочності, який передбачає подання інформації у доступній для студента формі;

- принцип індивідуалізації навчання, який має на увазі врахування викладачем індивідуальних психологічних особливостей студента під час педагогічного забезпечення самостійної роботи;

- принцип інтерактивності, що включає обмін інформацією з навчальної дисципліни як з викладачем, так з іншими студентами;
- принцип зворотного зв'язку, який дозволяє студенту і викладачу своєчасно обговорювати та корегувати проблемні питання з навчальної дисципліни;

- принцип зовнішнього контролю та самооцінки, що забезпечує контроль самостійної роботи студента з боку викладача, який актуальний при використанні технічних засобів (відеоконференц-зв'язок);

- принцип міцності засвоєння знань, який передбачає контроль залишкових знань і умінь через певний час після завершення вивчення дисципліни.

У міжсесійний період самостійна робота студентів заочної форми навчання з дисципліни “Біологічна хімія” полягає у вивченні матеріалів за підручниками, монографіями, науковими статтями і написанні на основі опанованого матеріалу контрольної роботи з біологічної хімії. Контрольна робота, будучи однією із форм перевірки та оцінки засвоєння знань студентами заочної форми навчання, дозволяє отримати інформацію про характер пізнавальної діяльності, рівень самостійності та активність студента у навчальному процесі, ефективність методів, форм і способів навчальної діяльності. Важливо, щоб система завдань для письмової контрольної роботи передбачала як виявлення у студентів знань з певної теми, так і розуміння біохімічних механізмів регуляції гомеостазу організму, вміння самостійно робити висновки і узагальнення. Таким чином, на сесію студенти приходять маючи певний базовий рівень знань і питань з біологічної хімії. Остаточне вивчення навчальної дисципліни “Біологічна хімія” закріплюється під час аудиторних занять шляхом слухання лекцій та участю в практичних заняттях. Для підготовки до практичного заняття з біологічної хімії студенти заочної форми навчання використовують такі форми СРС, як роботу над конспектом лекції, підбір, вивчення, аналіз і конспектування основної та додаткової навчальної літератури, виконання практичних завдань (вирішення ситуаційних задач та тестових завдань, відповіді на питання, заповнення таблиць, побудова схем метаболічних шляхів вуглеводів, ліпідів та білків в організмі людини тощо).

Найважливішою умовою ефективності самостійної роботи студентів заочної форми навчання $€$ створення навчально-методичної літератури підручників, посібників, презентацій й тез лекцій, методичних вказівок із завданнями для самостійної роботи, збірок тестових завдань для перевірки рівня успішності засвоєння студентами кожної теми [5]. Навчальні матеріали для СРС методично організовані таким чином, щоб компенсувати від- 
сутність контакту студента з викладачем. У методичних вказівках для виконання самостійної роботи студентів заочної форми навчання з дисципліни “Біологічна хімія”, по-перше, відображаються назва теми практичного заняття, мета підготовки до нього, теоретичні питання, на які студенту необхідно надати відповідь під час вивчення конкретної теми, по-друге, описуються методики проведення якісного або кількісного дослідження показників обміну речовин та клініко-діагностичне значення біохімічного аналізу, по-третє, наводиться список основної та додаткової літератури з посиланням на інтернет-ресурс. Методичні матеріали містять систему опорних орієнтирів (визначення, біохімічні терміни тощо), які допомагають студентам оперативно скласти загальне уявлення про будову біомолекул, біохімічні процеси в організмі людини та їх регуляцію, орієнтуватися у змісті навчального матеріалу, швидко знаходити необхідну інформацію. Велике значення мають різні таблиці біохімічних показників, схеми біохімічних реакцій, графіки, рисунки, що допомагають студентам створити зрозумілу картину взаємодії метаболічних шляхів біоорганічних сполук, їх впорядкованість, регуляцію та патологію. Навчально-методичні матеріали обов’язково включають завдання для самоконтролю, що актуально в умовах кредитно-модульної системи організації навчального процесу. Завдання для СРС мають активний і творчий характер, стимулюють пошук самостійних рішень, включають еталони відповіді або запропоновані варіанти вирішення тієї чи іншої проблеми, а також ключі для визначення правильності їх виконання. Під час самостійної роботи студент сам перевіряє свої знання i, у випадку необхідності, може виконати завдання повторне після отримання результату.

Розвиток сучасної освіти, пов’язаний з використанням інформаційних та комунікаційних технологій у навчальному процесі, впливає на зміни форм і методів СРС. Завдяки інформаційнокомунікаційним технологіям поєднуються процеси вивчення, закріплення і контролю засвоєння навчального матеріалу, що сприяє підвищенню у студентів мотивації до навчання, розвитку креативного мислення, дозволяє економити навчальний час. Інтерактивність і мультимедійна наочність дозволяє студентам краще засвоїти великий обсяг навчального матеріалу. Для забезпечення і проведення СРС з дисципліни “Біологічна хімія” впроваджуються комп’ютерні навчальні програми, зокрема електронні підручники, навчальні відеофільми, відеопрактикуми, анімаційні малюнки, презентації лекцій. Це дозволяє організувати проблемне навчання, у якому студент є рівноправним учасником навчального процесу.

Результативність СРС визначається наявністю різних видів її контролю [6]. На початку вивчення конкретної теми з біологічної хімії проводиться вхідний контроль знань і умінь студентів. Рівень засвоєння матеріалу студентами на практичних заняттях відстежується через поточний тестовий контроль. Незважаючи на високу трудомісткість розробки матеріалів для тестового контролю, проведення його у комп’ютерному варіанті скорочує час на перевірку результатів, об’єктивно оцінює знання студентів, дає можливість виявити структуру знань студентів і на цій основі переоцінити методичні підходи до навчання з навчальної дисципліни. Рівень теоретичної та практичної підготовки студентів заочної форми навчання відповідно до робочої навчальної програми дисципліни “Біологічна хімія” оцінюється під час проведення підсумкового модульного контролю (ПМК). До ПМК допускаються студенти, які виконали та захистили контрольну роботу (не менше 50 балів), відвідали всі аудиторні навчальні заняття та при вивченні навчального матеріалу набрали кількість балів, не меншу за мінімальну (оцінка “3” в балах $\times$ на кількість занять). Підготовка до ПМК є одним із найбільш відповідальних видів самостійної роботи студентів заочної форми навчання. Для визначення рівня підготовки студентів застосовуються тестові завдання, ситуаційні задачі, демонстрація практичних навичок дослідження речовин у біологічних рідинах з подальшою інтерпретацією отриманих результатів. Оцінка успішності студента з дисципліни “Біологічна хімія” є рейтинговою і визначається за системою ЄKTC та шкалою, яка прийнята в Україні [3].

Висновок. Таким чином, орієнтація навчального процесу на збільшення обсягу годин для СРС і підвищення ефективності самостійної роботи студентів заочної форми навчання передбачає: 1) підготовку викладачами навчально-методичної літератури (підручники, навчальні та навчальнометодичні посібники, комп’ютерні навчальні програми, відеопрактикуми тощо), що дозволяють самостійно опанувати дисципліну; 2) створення матеріально-технічної бази вищого навчального закладу - комп’ютерні класи, лабораторії і спеціальні аудиторії для СРС; 3) організацію постійних консультацій та консультаційної служби, видачу комплекту завдань для СРС поетапно; 4) розвиток системи дистанційної освіти. 


\section{Список літератури}

1. Про особливості впровадження кредитномодульної системи організації навчального процесу : наказ МОН України від 20.10.04 № 812.

2. Про вищу освіту : Закон України від 01.07.14 № 1556-VII BP.

3. Про запровадження у вищих навчальних закладах України Європейської кредитно-трансферної системи : наказ МОН України від 16.10.09 № 943.

4. Система професійної безперервної підготовки лікарів для охорони здоров’я України/ [В. Ф. Москаленко, М. В. Банчук,Т. Д. Бахтеєва та ін.].- К. : Книга-плюс, 2009. - 64 c.
5. Кулик $Є$. Дидактична характеристика процесу самоосвіти / Є. Кулик // Вища освіта України : теоретичний та науково-методичний часопис. - 2006. № 1. - С. 102-107.

6. Самостоятельная работа студентов в условиях кредитно-модульной системы / И. В. Ниженковская, О. А. Глушаченко, О. И. Головченко, О. В. Манченко // Научная дискуссия: вопросы педагогики и психологии. № 1(22) : сб. статей по материалам XXII Междунар. заоч. науч.-практ. конф. - М. : Изд-во “Международный центр науки и образования”, 2014. - С. 72-77.

Отримано 02.11.15 